\title{
Implementation of Excellent Private Madrasah Ibtidaiyah Programs in Rural Areas
}

\author{
Ahmad Gawdy Prananosa \\ STKIP PGRI Lubuklinggau \\ ahmadgawdyprananosa2020@gmail.com \\ Donni Pestalozi \\ STKIP PGRI Lubuklinggau \\ pestalozid@gmail.com \\ M. Rusni Eka Putra \\ STKIP PGRI Lubuklinggau \\ ekaputra@stkippgri-lubuklinggau.ac.id
}

\begin{abstract}
This study aims to determine the implementation of the flagship program of private madrasah ibtidaiyah in rural areas. Using a qualitative approach with phenomenological methods. It was held at Madrasah Ibtidaiyah Assidiq Giriyoso, Jayaloka District. The research subjects consisted of the Principal, the Board of Teachers, and the Foundation. Data collection technique; observation, interview and documentation. The data analysis step uses an interactive model from Miles and Huberman. The results of the research show that the implementation of the madrasah flagship program is implemented well, namely: 1) the material is delivered according to the ability level of the students, 2) the material delivered has been planned in the learning implementation plan, 3) the teacher is prepared to focus on the abilities of each student, so that the material what is conveyed can be easily accepted by students, 4) facilities and infrastructure, especially tabfir boarding schools are prepared in front of their respective classes, 5) the curriculum prepared is in accordance with the analysis of students' abilities, which are listed in the learning implementation plan, 6) finances, especially in giving honorarium for teaching staff, according to the number of working hours that have been carried out, and 7) relations with the community are always well established, especially in supporting madrasah flagship programs, because the community is an important element in using products from madrasah. In conclusion, the implementation of the flagship program of tahfiz. al-qur'an and English can really have a positive impact on the development of madrasah, because the alumni of madrasah ibtidaiyab Giriyoso are able to compete academically with other students, at the state junior high school level, so that parents entrust their children to school in madrasah.
\end{abstract}

Keywords: Featured Program; Private Madrasab Ibtidaiyah

Abstrak: Penelitian ini bertujuan untuk mengetabui implementasi program unggulan madrasab ibtidaiyah swasta di pedesaan. Menggunakan pendekatan kualitatif dengan metode fenomenologi. Dilaksanakan di Madrasah Ibtidaiyah Assidiq Giriyoso Kecamatan Jayaloka. Subyek penelitian terdiri dari Kepala Sekolah, Dewan Guru, Pibak Yayasan. Teknik pengumpulan data; observasi, wawancara dan dokumentasi. Langkah analisis data menggunakan interactive model dari Miles dan Huberman. Hasil penelitian, implementasi program unggulan madarasah diterapkan secara baik, yakni: 1) materi disampaikan sesuai dengan tingkat kemampuan peserta didik, 2) materi yang disampaikan sudah direncanakan dalam rencana pelaksanaan pembelajaran, 3) guru dipersiapkan untuk, fokus dengan kemampuan setiap peserta didik, agar

Tadbir : Jurnal Studi Manajemen Pendidikan Vol. 5, No. 2, November 2021

IAIN Curup - Bengkulu |p-ISSN 2580-3581;e-ISSN 2580-5037 
materi yang disampaikan dapat dengan mudah diterima oleh siswa, 4) sarana dan prasarana terutama pondok tahfiz disiapkan berada didepan kelas masing-masing, 5) kurikulum yang dipersiapkan sudab sesuai dengan analisis kemampuan siswa, yang tercantum dalam rencana pelaksanaan pembelajaran, 6) keuangan terutama dalam pemberian honor tenaga pengajar, sesuai dengan jumlah jam kerja yang telah dilaksanakan, dan 7) bubungan kepada masyarakat selalu terjalin dengan baik, terutama dalam mendukung program unggulan madarasah, karena masyarakat merupakan elemen penting dalam menggunakan produk dari madrasah. Simpulan, penerapan program unggulan tahfiz al qur'an dan bahasa inggris benar-benar dapat memberikan dampak positif dalam pengembangan madarasah, sebab alumni madarasah ibtidaiyah Giriyoso mampu bersaing secara akademik dengan siswa yang lainnya, pada jenjang sekolah menegabh pertama (SMP) Negeri, sehingga orang tua siswa mempercayakan anaknya sekolah di madrasah.

Kata Kunci: Program Unggulan; Madrasah Ibtidaiyah Swasta

\section{INTRODUCTION}

The implementation of madrasah is in accordance with national education standards formulated by the Government. Government Regulation No. 19 of 2005 covers education staff educator standards, process standards, content standards, financing standards, infrastructure standards, management standards, graduate competency standards, and assessment standards. The process of standardizing the implementation of education, it is hoped that madrasah are able to compete with public schools, especially in the implementation of general education. Moreover, in the education management process, the government has pushed for educational autonomy. Thus madrasah can be more flexible in carrying out school management processes that lead to improving the quality of madrasah.

Realizing flagship madrasah has become a must so that madrasah can become educational institutions that integrate general knowledge and leading religion in producing a generation of believers and knowledge. Wahid's research results (2018) there are four fundamentalist strategic pillars in exploring the potential of madrasah excellence, namely: 1) generate motivation, motivation is the foundation of everything to be achieved, 2) reading opportunities, 3) skills time management, and 4) Diligent and tenacious. Then the results of Yusuf's research (2019) to achieve the goal of becoming a flagship madrasah, it requires mature management, support from various parties, and supporting infrastructure.

Madrasah have flagship potential in their development, because madrasah can integrate general and religious knowledge, meaning that students can be equipped with religious and general knowledge while studying at madrasah. The results of Raisin's research (2016) actually have high capital better or more advanced than public schools to make he is qualified. Quality schools can be seen from a clear vision, mission, professional manager and have a good plan. The results of Yusra's research (2014) state that discipline, 
maximally empowered teacher resources and administrative staff, parental support, fulfillment of curriculum needs that are in accordance with local conditions, availability of facilities and infrastructure, optimally managing financing are factors that support the realization of flagship madrasah.

All school components can be a supporting factor in the development of flagship madrasah and also a cooperative network can also be a determinant in realizing flagship madrasah. The results of Hanun's research (2016) state that the supporting factor in developing flagship class is the formation of a curriculum development team collaboration network, but the inhibiting factor is the readiness of students who have not been maximized in participating in the flagship class program. The development of excellent madrasah also cannot be separated from the principal's strategy, the results of research by Ahmad, et.al (2017), the strategies made by school principals are, increasing the teaching ability of teachers, optimizing the use of media and educational facilities, carrying out routine supervision, collaborating with the community and implementing strict discipline that is always carried out.

Many previous studies have explained about strategies for developing flagship madrasah, flagship madrasah management, supporting factors for developing flagship classes in madrasah, the role of human resources in developing flagship madrasah, but this research focuses on implementing flagship madrasah programs, namely tahfiz houses and students' English language skills. Where graduates of madarash ibtidaiyah giriyoso are able to compete for achievement in public junior high schools (SMP) in the academic field, so this has attracted the attention of student guardians to entrust their children to school at Madrasah Ibtidaiyah Giriyoso. So that madrasah are really able to integrate religious and general knowledge in creating a generation that has religious and general knowledge.

\section{RESEARCH METHODS}

This study uses a qualitative approach with phenomenological methods. The phenomenological method aims to describe the meaning of the experience of implementing the flagship program of the Madrasa Ibtidaiyah Assidiq Giriyoso in improving the quality of graduates. This research was conducted in Madrasah Ibtidaiyah Assidiq Giriyoso, Jayaloka District, Musi Rawas Regency. The research is carried out directly from the field within a certain period, a few weeks, a few months or the length of time demanding the adequacy of the data obtained. During the research, the researcher tries to make or create social interaction relationships and tries to understand the real situation what is happening in the field. 
The research subjects consisted of the Principal, the Board of Teachers, the Foundation. Data collection technique; observation, interview and documentation. The data analysis step in this research uses an interactive model from Miles and Huberman, where the analysis process is carried out simultaneously with the observation and interview processes and direct documentation is analyzed. With this interactive model, it is possible to analyze data in the field when researchers are conducting research or after returning from research. So in qualitative research there is flexibility in patterns or methods, however, researchers must be careful, sensitive so that in digging up data they can explain the facts or what actually happened.

The data analysis step with this model consists of activity stages, namely: data collection, data reduction, data presentation and data inference. Data collection was carried out by means of observation, interviews and documentation studies. The data obtained in the field are recorded in the form of field notes, namely a description of the data obtained. Reduction is the process of selecting data, which are relevant to answer the researcher's questions. After the reduction, a more focused component was determined to be observed and interviewed again.

\section{RESULT}

Students who take part in the tahfiz al-qura'n and English programs are really serious about being taught, so that the programs implemented can run well. The results of an interview with one of the teachers are as follows:

"We provide material to students, of course, first of all, prepare a learning implementation plan (RPP), and so that the material presented can be easily conveyed to students and students can also easily receive the material"

Students sometimes have diverse abilities and creativity, thus demanding the role of a good teacher in delivering material to students. Teachers in this case educators must first understand the abilities of their students, so that in delivering learning materials according to students' conditions, it is very important the role of teachers in implementing the tahfiz al-qur'an and English program in madrasah. The results of interviews with school principals are as follows:

"Indeed, teachers must be ready to provide learning materials to students, especially in nurturing and educating students in flagship programs, so we always remind teachers to focus on delivering material in fostering madrasah flagship programs, because this program can attract parents to entrust their children to the madrasab"

Besides teachers and students, in the implementation of madrasah programs, supporting facilities and infrastructure are needed, so that program 
implementation can be achieved properly. Facilities and infrastructure are prepared so that the implementation of the program can run smoothly, including chairs, tables, and others that support the implementation of the program, the facilities and infrastructure that are prepared should be in good condition and can be used properly as well. The results of interviews with school principals are as follows:

"The facilities and infrastructure that we have prepared are up to standard and can be used properly, to support the smooth implementation of the tabfir qur'an and English language program in our Madrasab"

Good and quality facilities and infrastructure according to standards are very supportive in the smooth implementation of the tahfiz Qur'an and English language programs. Likewise, the curriculum that is made is very important in the implementation of the tahfiz Qur'an and English language programs. The curriculum should be designed as attractive as possible and easy for students to accept, but if the curriculum made does not pay attention to the needs of users, in this case students, then the implementation of the madrasah flagship program cannot run well. The results of an interview with one of the teachers are as follows:

"We make the curriculum contained in the learning implementation plan in accordance with the conditions of students, so that the implementation of learning can run well"

In addition to the curriculum, financial management is very important, especially in the provision of honorarium for teaching staff, so that in carrying out their duties, teachers really carry out their duties and meet expectations. However, if it is not paid according to the work done, the teacher will become less enthusiastic so that it will have an impact on the results of his work, namely students cannot receive the material properly and the planned program is not implemented properly. The results of interviews with the chairman of the foundation are as follows:

"Yes, we have budgeted the honorarium for teachers according to their work, so that teachers can really focus on carrying out their duties, especially in fostering tabfiz, alqur'an and English activities".

Public relations need to be maintained properly, because the community is an important element in using products from madrasah. The community will be interested and support madrasah if madrasah management can be carried out and implemented properly, especially in producing flagship generations, but if madrasah do not provide flagship products to the community, the level of 
confidence of parents to entrust their children to madrasah is very low. The results of an interview with one of the teachers are as follows:

"Relationships with the middle class society are very important, so that the community knows the condition and progress of the madrasa, with the success of the tahfir and English programs that we implement, it can be easily accepted by the community, especially to entrust their children to our madrasab"

The application of students, educators and education staff, facilities and infrastructure, finance and public relations is a determining factor in the successful implementation of madrasah flagship programs, with the implementation of flagship programs well, it can easily convince parents to entrust their children to madrasah.

\section{DISCUSSION}

The implementation of madrasah flagship programs, namely tahfiz al'qur'an and English can really have a positive impact on the development of Madrasah Ibtidaiyah Giriyoso, where parents believe students to entrust their children to school in madrasah, because madrasah are able to integrate religious knowledge (tahfiz qur'an) and general (English) while educating students at madrasah. The two excellent madrasah programs can be seen in quality when madrasa alumni continue their education to state junior high schools (SMP), which are able to compete academically with other students.

The implementation of the madrasah flagship program is implemented properly, where students are prepared to take part in the flagship program, the ability of students is used as the basis for providing material, so that the material is delivered according to the level of ability of the students, the material delivered has been planned in the learning implementation plan. Teacher readiness is also a determining factor in the success of madrasah flagship programs; teachers are prepared to focus on the abilities of each student, so that the material presented can be easily accepted by students.

The facilities and infrastructure have been well prepared, especially the tahfiz cottage which is in front of the class which is in accordance with the standards, and also the curriculum that is prepared is in accordance with the analysis of students' abilities, which are listed in the learning implementation plan. Then finance, especially in the provision of honorarium for teaching staff, in accordance with the number of working hours that have been carried out. Besides that, relations with the community are always well established, in terms of supporting the madrasah flagship program, because the community is an important element in using products from madrasah. 
Madrasah are able to integrate general and religious knowledge in their implementation, where students not only study religious knowledge but also general knowledge. The results of Hadi's research (2016) The madrasah administration system is the result of a modification of the system the implementation of pesantren because before the madrasah system was formed, at first the process of education and teaching is carried out in mosques and Islamic boarding schools. By in general, madrasah are the same as other schools, namely educational institutions which uses the classical system and classes with all the facilities except for the aspects of tradition and the implemented curriculum. The position of madrasah is juridical the same, especially in the aspect of the curriculum (Permendiknas no. 22, 23, 24 of 2006), However, madrasah in general still maintain their characteristics as schools with Islamic characteristics.

Then, the results of Siswanto's research (2014) show that the idea of realizing flagship madrasah in Islamic boarding schools is directed at integrating excellence in the intellectual and skill fields with excellence in the field of education. Religious knowledge includes excellence in the fields of personality, faith and piety. The results of Habibi's research (2020) that madrasah are the pride of this beloved nation.

Madrasah were born because of the initiative from the community, not from the government, so that the community itself sacrificed physically and mentally to live and develop it. This strong sense of ownership makes the community fully hope that the madrasah they love will survive and develop, so that it becomes a source of pride. Unfortunately, many madrasah are still lagging far behind public schools. Not a few opinions that arise in the community that madrasah are educational institutions that are out of date and synonymous with backwardness. They are reluctant to entrust their children to madrasah because they are afraid that their children will not be ready to compete in the challenges of globalization. This negative perception of some people does not need to be responded to excessively, apologetic, and defensively. Madrasah must be challenged to answer this minor accusation with serious steps to improve quality in all aspects. There are many things that become the homework of madrasah managers, ranging from improving the quality of teachers, developing students' talents, expanding cooperative networks, to procuring adequate facilities and infrastructure.

\section{CONCLUSION}

The implementation of the flagship program of private Madrasah Ibtidaiyah in Giriyoso Village, namely the tahfiz al'qur'an and English programs can really have a positive impact on the development of madrasah, because the 
alumni of Madrasah Ibtidaiyah Giriyoso are able to compete academically with other students, at the state junior high school (SMPN), thus making parents entrust their children to school in madrasah. Madrasah flagship programs are implemented by taking into account; 1) the material is delivered according to the ability level of the students, 2) the material delivered has been planned in the learning implementation plan, 3) the teacher is prepared to focus on the abilities of each student, so that the material presented can be easily accepted by students,4) facilities and infrastructure, especially tahfiz boarding schools are prepared in front of each class, 5) the curriculum is prepared in accordance with the analysis of student abilities, which is listed in the learning implementation plan, 6) finances, especially in the provision of honorarium for teaching staff, according to the number of hours worked that have been implemented, and 7) relations with the community are always well established, especially in supporting madrasah flagship programs, because the community is an important element in using products from madrasah.

\section{REFERENCES}

Ahmad, Y., Devi, A., \& Ridoan, N. (2017). Strategi Kepala Madrasah dalam Mewujudkan Madrasah Unggulan di MIN 3 Simpang Tiga Kecamatan Bukit Raya Kota Pekanbaru, Jurnal Al-Hikmah, 14(2), 136-159

Alawiyah, F. (2014). Pendidikan madrasah di Indonesia. Aspirasi: Jurnal Masalahmasalah Sosial, 5(1), 51-58.

Douglass, S. L., \& Shaikh, M. A. (2004). Defining Islamic Education: Differentiation and Applications. Current Issues in Comparative Education, 7(1), 5-18.

Fathurrochman, I., Endang, E., Bastian, D., Ameliya, M., \& Suryani, A. (2021). Strategi Pemasaran Jasa Pendidikan Dalam Meningkatkan Nilai Jual Madrasah Aliyah Riyadus Sholihin Musirawas. Jurnal Isema: Islamic Educational Management, 6(1), 1-12.

Habibi, N. (2020). Manajemen Pengembangan Madrasah yang Unggul dan Kompetitif, Southeast Asian Journal of Islamic Education Management, 1(2), $130-145$

Hadi, S. (2016). Dinamika Madrasah dan Sistem Penyelenggaraan Pendidikan Islam Unggulan, Tarbiyatuna: Jurnal Pendidikan Islam, 9(2), 143-173

Hakim, L. (2020). The Participation of the Community in Enhancing Education Quality. Attractive: Innovative Education Journal, 2(1), 177-188.

Hanun, F. (2016). Membangun Citra Madrasah melalui Program Kelas Unggulan di MTsN 2 Bandar Lampung. Edukasi: Jurnal Penelitian Pendidikan Agama dan Keagamaan, 14(3), 405-424 
Hasanah, A., \& Kultsum, U. (2020). How Principals of Madrasah Ibtidaiyah Negeri Dealt with Obstacles. Jurnal Manajemen Pendidikan: Jurnal Ilmiah Administrasi, Manajemen dan Kepemimpinan Pendidikan, 2(2), 178-191.

Khaidir, E., \& Suud, F. M. (2020). Islamic education in forming students' characters at as-shofa Islamic High School, pekanbaru Riau. International Journal of Islamic Educational Psychology, 1(1), 50-63.

Lahmar, F. (2020). Islamic education: An Islamic "wisdom-based cultural environment" in a western context. Religions, 11(8), 409.

Nuryana, Z., \& Fauzi, N. A. F. (2020). The Fiqh of disaster: The mitigation of covid-19 in the perspective of Islamic education-neuroscience. International Journal of Disaster Risk Reduction, 51, 101848.

Parker, L., \& Raihani, R. (2011). Democratizing Indonesia through education? Community participation in Islamic schooling. Educational Management Administration \& Leadership, 39(6), 712-732.

Rasi in. (2016). Menakar Standar Madrasah Bermutu, KORDINAT, 15(1), 7588

Raudah, R., Hidir, A., \& Nor, M. (2021). Understanding Educational Management in The Context of Environmental Protection for Madrasah Application. Naz̧bruna: Jurnal Pendidikan Islam, 4(2), 419-433.

Rizkiyah, R., Istikomah, I., \& Nurdyansyah, N. (2020). Strategies to Build a Branding School in Efforts to Improve the Competitiveness of Islamic Education Institutions. Proceedings of The ICECRS, 7.

Shah, S. Z. H., Fathurrochman, I., Ayub, A., Altamirano, G. C., Rizwan, A., Núñez, R. A. S., Sabir, Z \& Yeskindirova, M. (2021). Inclined magnetized and energy transportation aspect of infinite shear rate viscosity model of Carreau nanofluid with multiple features over wedge geometry. Heat Transfer. https://doi.org/10.1002/htj.22367

Siswanto. (2014). Madrasah Unggulan Berbasis Pesantren, Ulumuna: Jurnal Studi Keislaman, 18(1), 159-180

Usri, U., Saparuddin, S., Bani, S., Abdullah, A., \& Lambe, H. (2021). The Contribution of Islamic School as Media of Developing Nation Culture. Al-Musannif, 3(1), 53-66.

Wahed, A. (2018). Strategi Mewujudkan Sekolah dan Madrasah Unggulan di Era Global, Al-Ibrah, 3(1), 1-28

Wahyuni, R., Harmi, H., Fathurrochman, I., \& Endang, E. (2020). Implementasi Kurikulum 2013 pada Mata Pelajaran Aqidah Akhlak di SDIT BIN BAZ Kabupaten Rejang Lebong. Jurnal Darussalam: Jumal Pendidikan, Komunikasi dan Pemikiran Hukum Islam, 12(1), 1-16.

Yusra. (2014). Implementasi Manajemen Sekolah Unggulan di Indonesia, Jurnal Diskursus Islam, 2(3), 335-353 
212 |Tadbir : Jurnal Studi Manajemen Pendidikan, Vol. 5, No. 2, 2021

Yusuf, M. (2019). Perkembangan Madrasah Formal di Indonesia, INTIZAM: Jurnal Manajemen Pendidikan Islam, 2(2), 135-146

Zaini, M. F., \& Syafaruddin, S. (2020). The Leadership Behavior of Madrasah Principals in Improving the Quality of Education in MAN 3 Medan. Jurnal Iqra': Kajian Ilmu Pendidikan, 5(2), 95-106. 